$\underline{\text { ARTIGOS }}$

\title{
Fungicides, seed dresser adjuvants and storage time in the control of Drechslera teres in barley seeds
}

\author{
Erlei Melo Reis ${ }^{1,2}$, Anderson Danelli ${ }^{1}$ e Ricardo Trezzi Casa, ${ }^{2,3}$
}

${ }^{1}$ Universidade de Passo Fundo, RS; ${ }^{2}$ Bolsita do CNPq; ${ }^{3}$ Universidade Desenvolvimento de Santa Catarina, Lages, SC

Autor para correspondência: Erlei Melo Reis (erleireis@upf.br)

Data de chegada: 03/05/2011. Aceito para publicação em: 16/05/2012.

1749

\section{ABSTRACT}

Reis, E.M.; Danelli, A.L.D.; Casa, R.T. Fungicides, seed dresser adjuvants and storage time in the control of Drechslera teres in barley seeds. Summa Phytopathologica, v.38, n.3, p.187-191, 2012.

In experiments conducted in laboratory, the effect of fungicides, seed dresser adjuvants and storage time in the control of Drechslera teres in seeds of barley cultivar BRS Elis, with $58 \%$ incidence, was quantified. Fungicides indicated by barley research (carboxin + thiram, difenoconazole and triadimenol) compared with the mixture carbendazim + iprodione were tested. As seed dresser adjuvants, water $(500 \mathrm{~m} \mathrm{~mL} / 100 \mathrm{Kg})$ and a polymer $(150 \mathrm{~mL} / 100 \mathrm{Kg})$ were used. Treated seeds were stored in paper bags and kept in the refrigerator at $5^{\circ} \mathrm{C}$. At 30-day intervals during six months, seeds were plated on semiselective Reis's medium (1983). The best control was obtained by the mixtures carboxin + thiram and carbendazim + iprodione and the polymer as seed dresser. The control efficiency was improved by the storage time without negatively affecting seed germination. Due to the transmission efficiency, the fungus eradication in seeds should be pursued.

Additional keywords: Hordeum vulgare, net-blotch, seed pathology.

\section{RESUMO}

Reis, E.M.; Danelli, A.L.D.; Casa, R.T. Fungicidas veículos de cobertura e tempo de armazenamento no controle de Drechslera teres em sementes de cevada. Summa Phytopathologica, v.38, n.3, p.187-191, 2012.

Em experimentos conduzidos em laboratório quantificou-se o efeito de fungicidas, de veículos de cobertura e do tempo de armazenamento no controle de Drechslera teres em sementes de cevada cultivar BRS Elis com incidência natural de 58\%. Foram testados os fungicidas nas doses indicadas pela pesquisa de cevada (carboxina + tiram, difenoconazol e triadimenol) comparados com a mistura carbendazim + iprodiona. Como veículos testou-se a água $(500 \mathrm{~mL} /$ $100 \mathrm{~kg})$ e um polímero $(150 \mathrm{~mL} / 100 \mathrm{~kg})$. As sementes após o tratamento foram armazenadas em sacos de papel e mantidas em refrigerador a $5^{\circ} \mathrm{C}$. A intervalos de 30 dias, até completar três meses, as sementes foram plaqueadas em meio semi-seletivo de Reis (1983). O melhor controle foi obtido pelas misturas carboxina + tiram e carbendazim + iprodiona, com o veículo polímero. A eficiência do controle foi melhorada pelo tempo de armazenamento sem afetar negativamente a germinação das sementes. Devido à eficiência de transmissão a erradicação do fungo em sementes deve ser perseguida.

Palavras-chave adicionais: Hordeum vulgare, mancha-em-rede, patologia de sementes.

In the 2010 growing season in Brazil, barley crop was cultivated in an area of 80,000 ha, yielding a final production of $248,000 \mathrm{t}$. In that season, 200,000 sacks of seeds (40kg/sack) were sown (4).

The main fungi associated with barley seeds are those causing leaf spots such as net-blotch (Drechslera teres (Sacc.)Schoem), heminthosporiosis [Bipolaris sorokiniana (Sacc.) Shoem.], stripeblotch [D. graminea (Rabe.) Schoem], and scab [Gibberella zeae (Schw.) Petch]. The major inoculum sources of these pathogens are seeds and host crop residues (6).

The damage caused by barley net-blotch can be assessed by using the linear equation $\mathrm{y}=1,000-13.9 \mathrm{I}$ (where $\mathrm{y}=$ barley normalized grain yield $\mathrm{kg} / \mathrm{ha}$ ), I = leaf incidence (\%) (10).

Net-blotch control measures are focused on the development of cultivars especially resistant to $D$. teres and $B$. sorokiniana, crop rotation with plant species non-susceptible to target pathogens and, fungicide applied in seeds and sprayed on above-ground plant parts (12).

Little attention has been given to barley seeds as a source of inoculum for the necrotrophic fungi that cause leaf blotches and common root-rot. Currently, only three fungicides, or mixtures, are recommended for barley seed treatment (carboxin + thiram, difenoconazole and triadimenol) (12).

Nevertheless, their efficiency does not eradicate the pathogenic fungi infecting the barley seed. Moreover, the incidence in harvested seeds is high, further compromising the treatment effectiveness. As a result, everywhere barley is cultivated, there are always leaf blotches causing damage to the crop, even under crop rotation with nonsusceptible crops such as oats, rape, canola and hairy vetch (1).

The aims of this study were to (i) improve the performance of 
fungicides indicated by the barley research; (ii) compare their performance with the mixture carbendazim + iprodione; (iii) test two seed dresser adjuvants; and (iv) determine the effect of seed storage time on improving the control of $D$. teres in barley seeds.

\section{MATERIALAND METHODS}

Barley seeds of the cultivar BRS Elis were treated with fungicides (Table 1) on 08.15.2010 and stored in paper bags inside a refrigerator at $5^{\circ} \mathrm{C}$. Water $(500 \mathrm{~mL} / 100 \mathrm{~kg})$ and a polymer (Polyether copolymer Laborsan)(150 mL/100kg of seeds) were used as seed dresser adjuvants to improve seed coverage. Fungicides, seeds and seed dresser adjuvants were mixed in an Erlenmeyer flask by manually shaking until complete seed coverage.

Treated seeds were plated on Reis's (7) semi-selective medium contained in crystal acrylic boxes $(11 \times 11 \times 3.5 \mathrm{~cm}$ high $)($ Gerbox $)$ and incubated for $10-12$ days in a growth room at $25^{\circ} \mathrm{C}$ and $12 \mathrm{~h}$ photoperiod given by fluorescent lamps (four GE daylight $40 \mathrm{w}$ tubes)
$30 \mathrm{~cm}$ above the boxes. The evaluations were made on the 15 th day following the treatment and at 30-day intervals during four months of storage. Seed germination test was performed according to Brasil (2).

Experimental units consisted of four acrylic boxes, each one containing 25 seeds, totaling 100 seeds per replication in a $2 \times 7$ factorial arrangement, including the fungicides as one factor and the vehicle with and without the polymer as other factors, with four replicates. Data underwent analysis of variance and, when significant in the F test, were compared by Tukey's multiple range test at $p=0.05$. Experiments were repeated at least twice.

\section{RESULTS AND DISCUSSION}

There was significant interaction between the fungicides and the storage times $(15,30,60,90$, and 120 days) (Tables 1, 2, 3, 4 and 6). The data of $D$. teres incidence in the treatments were expressed in relation to the incidence in the control. Incidence values in the control are in the footnotes of Tables.

Table 1. In vitro control (\%) of Drechslera teres incidence in barley seeds treated with fungicides applied with two seed dresser adjuvants and plated at 15 days after treatment

\begin{tabular}{|c|c|c|c|c|}
\hline \multirow[b]{2}{*}{ Fungicides } & \multirow[b]{2}{*}{ Concentrations/doses ${ }^{\mathrm{z}}$} & \multicolumn{2}{|c|}{ Seed dresser adjuvants } & \multirow[b]{2}{*}{ Means } \\
\hline & & Water & Polymer & \\
\hline Carbendazim & $(50 \%) 100 \mathrm{~mL}$ & A $49.99 \mathrm{ab}$ & A $47.50 \mathrm{~b}$ & 48.74 \\
\hline Carboxin + thiram & $(75 \%+70 \%) 250 \mathrm{~mL}$ & A $87.50 \mathrm{a}$ & A $70.83 \mathrm{ab}$ & 79.16 \\
\hline Difenoconazole & $(15 \%) 200 \mathrm{~mL}$ & A $58.33 \mathrm{ab}$ & A $41.66 \mathrm{~b}$ & 49.99 \\
\hline Flutriafol & $(50 \%) 200 \mathrm{~mL}$ & B $29.16 \mathrm{~b}$ & A $68.74 \mathrm{ab}$ & 49.20 \\
\hline Iprodione & $(50 \%) 100 \mathrm{~mL}$ & B $60.41 \mathrm{ab}$ & A $91.66 \mathrm{a}$ & 76.03 \\
\hline Triadimenol & $(15 \%) 250 \mathrm{~mL}$ & A $70.83 \mathrm{ab}$ & A $81.24 \mathrm{ab}$ & 76.03 \\
\hline Carbendazim + iprodione & $100+100 \mathrm{~mL}$ & A $71.08 \mathrm{ab}$ & B $58.33 \mathrm{ab}$ & 64.70 \\
\hline Means & & $61.04 \mathrm{~A}$ & $65.71 \mathrm{~A}$ & \\
\hline CV $(\%)$ & & & & \\
\hline
\end{tabular}

Table 2. In vitro control (\%) of Drechslera teres incidence in barley seeds treated with fungicides applied with two seed dresser adjuvants and stored for 30 days

\begin{tabular}{|c|c|c|c|c|}
\hline \multirow[b]{3}{*}{ Fungicides } & \multicolumn{3}{|c|}{ Treatments } & \multirow[b]{3}{*}{ Means } \\
\hline & \multirow[b]{2}{*}{ Concentrations/doses ${ }^{\mathrm{z}}$} & \multicolumn{2}{|c|}{ Dresser adjuvants } & \\
\hline & & Water & Polymer & \\
\hline Carboxin + thiram & $(75 \%+70 \%) 250 \mathrm{~mL}$ & A $94.31 \mathrm{a}$ & A 99.13 a & 96.72 \\
\hline Difenoconazole & $(15 \%) 200 \mathrm{~mL}$ & A $85.33 \mathrm{ab}$ & A $91.37 \mathrm{ab}$ & 88.23 \\
\hline Triadimenol & $(15 \%) 250 \mathrm{~mL}$ & A $84.47 \mathrm{ab}$ & B $69.82 \mathrm{c}$ & 77.14 \\
\hline Carbendazim + iprodione & $100+100 \mathrm{~mL}$ & A $90.07 \mathrm{ab}$ & A $91.80 \mathrm{ab}$ & 90.93 \\
\hline Means & & $85.63 \mathrm{~A}$ & $86.75 \mathrm{~A}$ & \\
\hline$\overline{\mathrm{CV}}$ & \multicolumn{4}{|c|}{4.14} \\
\hline
\end{tabular}

Means followed by the same letter do not differ according to Tukey's test at $5 \%$. Lowercase letters compare means in the columns and uppercase letters compare means on the lines. $\left({ }^{\mathrm{Z}}\right)$ - Concentrations and doses for $100 \mathrm{~kg}$ of seeds. Control incidence $58.0 \%$. Joint analysis of two experiments. 
Table 3. In vitro control (\%) of Drechslera teres incidence in barley seeds treated with fungicides applied with two seed dresser adjuvants and stored for 60 days

\begin{tabular}{|c|c|c|c|c|}
\hline \multirow[b]{3}{*}{ Fungicides } & \multicolumn{3}{|c|}{ Treatments } & \multirow[b]{3}{*}{ Means } \\
\hline & \multirow[b]{2}{*}{ Concentrations/doses ${ }^{\mathrm{z}}$} & \multicolumn{2}{|c|}{ Dresser adjuvants } & \\
\hline & & Water & Polymer & \\
\hline Carbendazim & $(50 \%) 100 \mathrm{~mL}$ & B $67.96 \mathrm{c}$ & A 92.66 a & 80.31 \\
\hline Carboxin + thiram & $(75 \%+70 \%) 250 \mathrm{~mL}$ & A $90.08 \mathrm{ab}$ & A $99.13 \mathrm{a}$ & 94.60 \\
\hline Difenoconazol & $(15 \%) 200 \mathrm{~mL}$ & A 81.46 b & A $96.11 \mathrm{a}$ & 88.78 \\
\hline Flutriafol & $(50 \%) 200 \mathrm{~mL}$ & A $58.18 \mathrm{c}$ & B $48.27 \mathrm{~b}$ & 53.22 \\
\hline Iprodione & $(50 \%) 100 \mathrm{~mL}$ & A $92.23 \mathrm{ab}$ & A $97.41 \mathrm{a}$ & 94.82 \\
\hline Triadimenol & $(15 \%) 250 \mathrm{~mL}$ & B $62.92 \mathrm{c}$ & A 86.20 a & 74.58 \\
\hline Carbendazim + iprodione & $100+100 \mathrm{~mL}$ & A $95.68 \mathrm{a}$ & A 97.84 a & 96.76 \\
\hline Means & & $78.35 \mathrm{~B}$ & $88.23 \mathrm{~A}$ & \\
\hline $\mathrm{CV}(\%)$ & & & & \\
\hline
\end{tabular}

Means followed by the same letter do not differ according to Tukey's test at $5 \%$. Lowercase letters compare means in the columns and uppercase letters compare means on the lines. $\left({ }^{\mathrm{Z}}\right)$ - Concentrations and doses for $100 \mathrm{~kg}$ of seeds. Control incidence $58.0 \%$. Joint analysis of two experiments.

Table 4. In vitro control (\%) of Drechslera teres incidence in barley seeds treated with fungicides applied with two seed dresser adjuvants and stored for 90 days

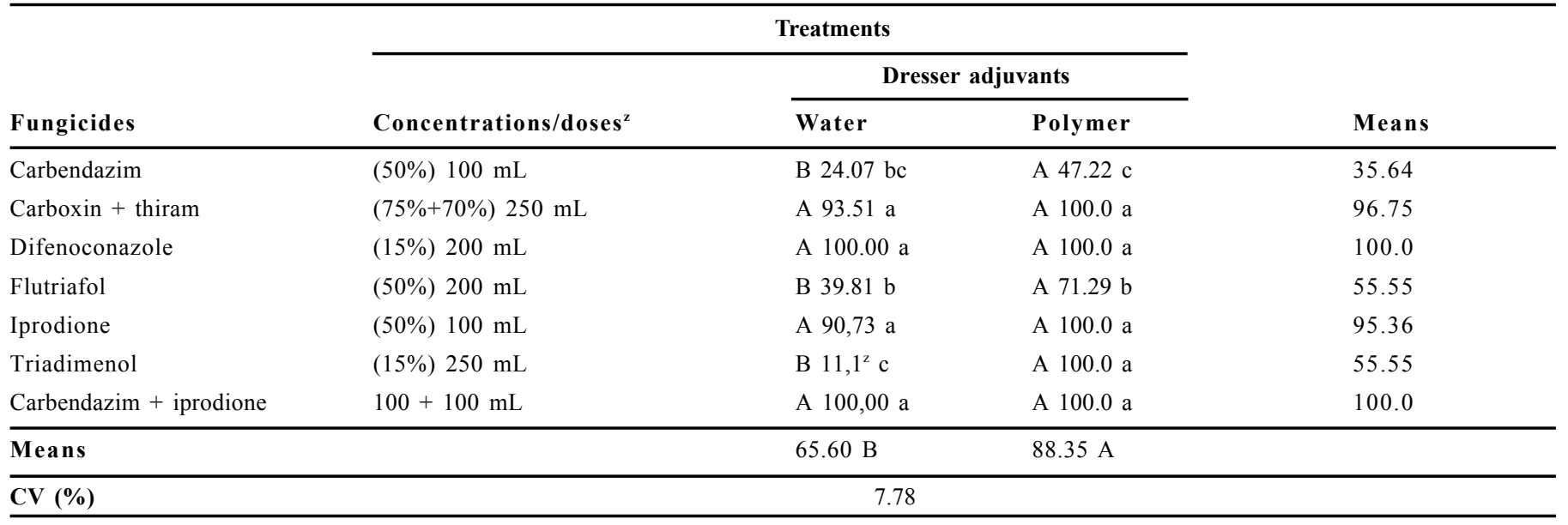

Means followed by the same letter do not differ according to Tukey test at $5 \%$. Lowercase letters compare means in the column and uppercase letters compare means on the line. $\left({ }^{2}\right)$ - Concentration and dose for $100 \mathrm{~kg}$ of seeds. Control incidence 58.0\%. Joint analysis of two experiments.

Table 5. Overall means of the effects of storage time of barley seeds treated with fungicides and two seed dresser adjuvants on the in vitro control (\%) of Drechslera teres

\begin{tabular}{clll}
\hline Storage time & \multicolumn{2}{l}{ Seed dresser adjuvants } & \\
\cline { 2 - 3 } (Days after treatment) & Water & Polymer & Means \\
\hline 1 & $61.04 \mathrm{~A}$ & $65.71 \mathrm{~A}$ & 63.38 \\
30 & $85.63 \mathrm{~A}$ & $86.75 \mathrm{~A}$ & 86.19 \\
60 & $78.35 \mathrm{~B}$ & $88.23 \mathrm{~A}$ & 83.29 \\
90 & $65.60 \mathrm{~B}$ & $88.35 \mathrm{~A}$ & 76.98 \\
\hline Means & 72.66 & 82.26 & - \\
\hline
\end{tabular}

Means of four seed assays (Tables 1 to 5 ) followed by the same upercase letter in the lines do not differ according to Tukey's test at $p=0.05$.
In general, seed companies perform seed treatment near sowing time (barley is seeded in May and June) (12). A large number of growers fear germination reduction by the water used as seed dresser and/or the fungicide phytotoxicity during storage. For this reason, seed treatment is performed close to seeding time.

Seed treatment effectiveness depends on chemical fungitoxicity, fungal sensitivity, and seed coverage quality (1). The fungicide that provides best control of dematiaceous (Bipolaris and Drechslera) fungi in seeds is iprodione, and for Fusarium spp., carbendazim (5, 11). Seed uncovered areas jeopardize the treatment effectiveness; thus, increasing the water volume improves coverage and fungicide effectiveness. However, it may interfere with germination during seed storage. Therefore, the use of nonaqueous adjuvants, such as polymers (Laborsan - www.laborsanbrasil.com), may be helpful to solve this problem. Benin (unpublished date) showed that the polymer alone presents some fungitoxic effect to $B$. sorokiniana in wheat seed.

Seeds treated with fungicides normally show better preservation 
Table 6. Effects of fungicides and seed dresser adjuvants on barley seed germination (\%) determined after 120 days of storage

\begin{tabular}{|c|c|c|c|c|}
\hline \multirow[b]{2}{*}{ Fungicides } & \multirow[b]{2}{*}{ Concentrations/doses ${ }^{z}$} & \multicolumn{2}{|c|}{ Seed dresser adjuvants } & \multirow[b]{2}{*}{ Mean } \\
\hline & & Water & Polymer & \\
\hline Carbendazim & $(50 \%) 100 \mathrm{~mL}$ & A $79.0 \mathrm{a}$ & A $80.0 \mathrm{~b}$ & 79.5 \\
\hline Carboxina + tiram & $(75 \%+70 \%) 250 \mathrm{~mL}$ & B 80.0 a & A $87.0 \mathrm{a}$ & 83.5 \\
\hline Difenoconazol & $(15 \%) 200 \mathrm{~mL}$ & A $79.0 \mathrm{a}$ & B $77.0 \mathrm{~b}$ & 78.0 \\
\hline Flutriafol & $(50 \%) 200 \mathrm{~mL}$ & B $74.0 \mathrm{~b}$ & A $78.0 \mathrm{~b}$ & 76.0 \\
\hline Iprodiona & $(50 \%) 100 \mathrm{~mL}$ & A $80.0 \mathrm{a}$ & B $68.0 \mathrm{c}$ & 70.0 \\
\hline Triadimenol & $(15 \%) 250 \mathrm{~mL}$ & A $70.0 \mathrm{~b}$ & B $69.0 \mathrm{c}$ & 69.5 \\
\hline Carbendazim + iprodiona & $100+100 \mathrm{~mL}$ & B $79.0 \mathrm{~b}$ & A $80.0 \mathrm{a}$ & 79.5 \\
\hline Mean & & $77.28 \mathrm{~B}$ & $77.0 \mathrm{~A}$ & \\
\hline CV $(\%)$ & & & 1.03 & \\
\hline
\end{tabular}

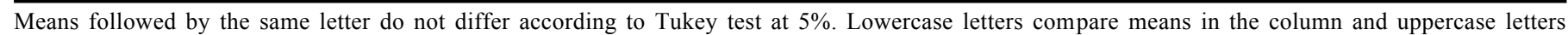
compare means on the line. $\left({ }^{z}\right)$ - Concentration and dose for $100 \mathrm{~kg}$ of seeds. Control germination $82 \%$.

during storage, with less risk of deterioration when the treatment was properly done (10).

Although little explored, fungicide exposure time (seed storage) can improve control when the goal is $100 \%$, to prevent field seed transmission and the pathogen introduction in the farm. Regardless of the seed treatment time (before or after storage), the effect of fungicides was similar, not affecting the physiological quality of soybean seeds (3).

When water was used as seed dresser, the best result was obtained by the mixture carboxin + thiram $(87.5 \%$ control $)$, while the polymer dresser, iprodione led to $91.66 \%$ control. As to the general mean, dressers did not differ, showing 61.66 and $65.71 \%$ control. The fungicides difenoconazole (49.99\%) and flutriafol (49.2\% control) were least effective. Considering the fungicides indicated by the research, carboxin + thiram, difenoconazole and triadimenol, only the mixture showed the best performance (Table 1).

Regardless of the dresser, the best result was obtained by the mixture carboxin + thiram, 94.31 and $99.13 \%$ control, and overall mean of $96.72 \%$. As to the general mean, the dressers did not differ, showing $85.63 \%$ and $86.75 \%$ control. Nevertheless, better than the control (Table 1) (with 61.66 and $65.71 \%$ ), 85.63 and 86.75 (Table 2) were obtained due to 30 days storage time. The fungicides flutriafol $(78.87 \%)$ and triadimenol (77.14\%) showed the lowest effectiveness (Table 2).

The best control with water and the polymer dresser in overall mean was obtained with iprodione $(92.23,99.13$ and $96.76 \%$, respectively). Seed dressing with polymer significantly improved control $(88.23 \%)$ over water $(78.35 \%)$.

Seed germination in the treatments with mixtures of fungicides carboxin + thiram (87\%) and iprodione + carbendazim (80\%) did not differ statistically. The treatment with carboxin + thiram increased germination relative to control.

The fungitoxicity was different for distinct fungicides, as well as the sensitivity of $D$. teres to treatments with fungicide. The most efficient mixtures were carboxin + thiram and iprodione + carbendazim.

The performance of a fungicide used for seed treatment depends on its fungitoxicity, the used level and the quality of seed surface coverage. The caryopsis surface roughness of small grains results in poor coverage and in lower control efficiency $(8,9)$. Seed dresser adjuvants, or coatings, are useful to overcome the difficulty in covering seed surface. Among them are water and non-aqueous coating such as polyethylene glycol (PEG) and polymers (1). The larger the used water volume for better coverage, the more efficient the control. However, high water volumes can initiate the germination of treated and stored seeds. Therefore, the use of non-aqueous vehicles is more advantageous, although more expensive.

Storage by itself for some period of time can reduce the longevity of some pathogenic fungi associated with wheat seeds such as $B$. sorokiniana (14) and $F$. graminearum Schwab in wheat seeds (13).

When seed treatment is not capable of preventing seed transmission to above-ground plant parts, it is considered ineffective, not reaching its objectives.

As the main sources of $D$. teres inoculum are seeds and crop residue, control measures should be directed to these sources such as seed treatment, as explained above, along with crop rotation $(6,9$, 10).

In this study, there was a reduction in fungal viability when carboxin + thiram or iprodione + carbendazim were used, reaching a control efficacy that can prevent the introduction of pathogens into new areas. Increasing storage time did not affect germination, and the treatments with the polymer dresser showed higher germination and greater control than those with water.

\section{REFERENCES}

1. Barba, J.T.; Reis, E.M.; Forcelini, C.A. Efeito de solventes orgânicos usados como veículos de fungicidas no controle in vitro e in vivo da incidência e da transmissão de Bipolaris sorokiniana em sementes de cevada. Fitopatologia Brasileira, Brasília v. 27 n. 4 p. 136-142. 2003.

2. Brasil. Ministério da Agricultura e do Abastecimento. Regras para análise de sementes. Brasília: SNAD/DNPV/CLAV, 1992. 365 p.

3. Conab. Disponível em: < http://www.conab.gov.br/olalacms/uploads/arquivos/ee9b65650e13403f19f724263401b977..pdf >(2011) Acesso em 12/03/2011.

4. Hewitt, H. G. Fungicides in crop protection. CAB International. Chapter, 4. Fungicide Performance. p. 87-153.1998.

5. Mahtre, D.E. Compendium of barley diseases. St. Paul: The American Phytopathological Society. 1982. 78 p.

6. Reis, E.M. Selective medium for isolating Cochliobolus sativus from soil. Plant Disease, St. Paul, n. 67, p. 68-70, 1983.

7. Reis, E.M. Doenças do trigo: podridão comum de raízes (Hel- 
mintosporiose). São Paulo: Companhia Nacional De Defensivos Agrícolas, 1988. 20 p.

8. Reis, E.M.; Casa, R.T. Patologia de sementes de cereais de inverno. Passo Fundo: Aldeia Norte, 1998. 88 p.

9. Reis, E.M.; Casa, R.C. Doenças dos cereais de inverno: diagnose, epidemiologia e controle. Lages: Graphel, 2007. 176 p.

10. Reis, E.M.; Reis, A.C; Carmona, M.M. Manual de fungicidas: guia para o controle químico de doenças de plantas. 6. Ed. Passo Fundo: Universidade de Passo Fundo; 2010. 226 p.

11. Reunião Nacional de Pesquisa de Cevada (27, 2009/2010, Passo
Fundo). Informações técnicas para a Produção de Cevada Cervejeira. Organizado Passo Fundo. Embrapa Trigo, Brasília: Embrapa Transferência de Tecnologia, 2008. 98 p.

12. Telles Neto, F.X.B.; Reis, E.M.; Casa, R.T. Viabilidade de Fusarium graminearum em sementes de trigo durante o armazenamento. Summa Phytopathologica, v.33, n.4, p.414-415, 2007.

13. Vecchiato, M.H.; Lasca, C.C.; Valarini, P.J. Sobrevivência do fungo Helminthosporium sativum em sementes de trigo (Triticum aestivum) armazenadas. Fitopatologia Brasileira, Brasília, v.12, n.3, p.226-231. 1987. 